\section{ACETOXYCYCLOHEXIMIDE AND CYCLOHEXIMIDE CONVERT TRANSFORMED MORPHOLOGY OF ras-TRANSFORMED CELLS TO NORMAL MORPHOLOGY}

Sir:

The discovery of oncogenes gives a great impact on cancer research ${ }^{1}$. In humans, activation of oncogenes by mutagenesis such as point mutation and translocation, rearrangement and amplification of DNA fragments plays a critical role in the initiation of carcinogenesis and/or proliferation of cancer cells. This provides us with a more rational approach to find effective antitumor agents. Thus, it is a hopeful way for overcoming human cancer to find new inhibitors for oncogene products or their functions. In this line of screening program we isolated genistein from fermentation broths of Pseudomonas as a specific inhibitor for tyrosine protein kinase ${ }^{2,3)}$, a function of the src oncogene family. However, ras oncogenes are more interesting because they have been detected in a variety of human cancers $^{4)}$ at very high frequencies ${ }^{5)}$. As a result of screening, we found agents in the fermentation broths of some Streptomyces species which can convert the morphology of rastransformed mouse NRK cells back to normal and identified them as acetoxycycloheximide and cycloheximide. Here we described the results.

DULBECCO's modified EAGLE medium (DME) and minimal EAGLE medium (MEM) which did not contain methionine were purchased from Nissui Pharmaceutical Co. and fetal calf serum was from Filton Pty Ltd., Australia. Anti-RAS monoclonal antibody and p21 protein were purchased from Oncogene Science Inc., protein A from Pharmacia and rat IgG from Sigma Co. $\left[{ }^{35} \mathrm{~S}\right]$ Methionine was obtained from ICN Radiochemicals, U.S.A. Virginiamycin, capreomycin, lincomycin, puromycin and fusidic acid were supplied from Sigma Co., and chloramphenicol from Sankyo Co., Ltd, josamycin from Yamanouchi Pharmaceutical Co., Ltd. tetracycline and streptomycin from Meiji Seika Kaisha, Ltd., mitomycin from Kyowa Hakko Kogyo Co., Ltd., and blasticidin S from Kaken Pharmaceutical Co., Ltd. Thiostrepton was a kind gift of S. J. LUCANIA of The Squibb Institute. YMC-A312 column for HPLC, was obtained from Yamamura Chemical Co. and silicic acid from Merck.

NRK cells, Harvey sarcoma virus-transformed NRK (Hav-NRK) cells and Swiss3T3 cells transformed with abl gene (AbtX-33), Rous sarcoma virus-transformed $3 \mathrm{Y} 1$ (SRA) cells, Ki-ras transformed NIH3T3 cells and adenovirus-transformed 3Y1 (WY3) cells were generous gifts from HIROSHI Yoshikura, SadaAki KaWaI, NobUo Tsuchida and KAZUKO SHIRoKI of the University of Tokyo, respectively.

NRK and Hav-NRK cells were cultured in DME supplemented with $10 \%$ fetal calf serum in $5 \% \mathrm{CO}_{2}$, water-saturated incubator. For screening of microbial products, the Hav-NRK cells were seeded at $2 \times 10^{3}$ cells in $200 \mu 1$ in a 96 well plate and grown overnight at $37^{\circ} \mathrm{C}$. Test samples (usually $10 \mu \mathrm{l}$ ) were added to a well, incubation was continued for 15 to 17 hours at $37^{\circ} \mathrm{C}$, and then the cell morphology was observed under an optical microscope. Effects on the other cells were determined in a similar manner.

Inhibition of protein synthesis was determined by the method of $\mathrm{KERRIDGE}^{6}$ ) with a slight modification as follows: Hav-NRK cells grown in a $3.5-\mathrm{cm}$ diameter dish were collected by centrifugation, washed twice with $1 \mathrm{ml}$ each of MEM and then suspended in MEM. Ten $\mu$ l of solution containing acetoxycycloheximide or cycloheximide at an appropriate concentration was added and the mixture was incubated for 1 hour at $37^{\circ} \mathrm{C}$. Then, $10 \mu \mathrm{l}$ of $\left.{ }^{35} \mathrm{~S}\right]$ methionine $(1 \mu \mathrm{Ci} / \mathrm{ml})$ was added and the incubation was continued for an additional 30 minutes at $37^{\circ} \mathrm{C}$. After removing the medium and washing twice with $1 \mathrm{ml}$ of phosphate-buffered saline, $1 \mathrm{ml}$ of $5 \%$ TCA was added, and the mixture was kept for 30 minutes at $0^{\circ} \mathrm{C}$. Radioactivity of the precipitate dissolved in $200 \mu \mathrm{l}$ of $0.2 \mathrm{~N} \mathrm{NaOH}$ was determined by a liquid-scintillation counter.

Hav-NRK cells grown in a $6.0-\mathrm{cm}$ diameter dish were collected by centrifugation, washed twice with $1 \mathrm{ml}$ of MEM and then suspended in MEM. Ten $\mu 1$ of solution containing acetoxycycloheximide (48.9 $\mathrm{ng} / \mathrm{ml})$ or cycloheximide $(390 \mathrm{ng} / \mathrm{ml})$ and $10 \mu \mathrm{l}$ of $\left[{ }^{35}\right.$ S $]$ methionine $(100 \mu \mathrm{Ci})$ were added and the mixture was incubated overnight at $37^{\circ} \mathrm{C}$. After removing the medium and washing four times with $1 \mathrm{ml}$ each of phosphate-buffered saline at $4^{\circ} \mathrm{C}, 500 \mu \mathrm{l}$ of PBS-TDS $\left(\mathrm{Na}_{2} \mathrm{PO}_{4} 10 \mathrm{mM}, \mathrm{NaCl} 0.155 \mathrm{M}\right.$, Triton X-100 $1 \%$, sodium deoxycholate $0.5 \%$, SDS $0.1 \%$, sodium azide $0.2 \%$ and $\mathrm{NaF} 0.004 \%, \mathrm{pH} 7.2$ ) was added and the mixture was incubated for 10 minutes at $4^{\circ} \mathrm{C}$. The supernatant was collected by centrifugation at $15,000 \times g$ for 30 minutes. p21 protein in the supernatant was analyzed by using anti-RAS monoclonal antibody according to the Manual of the producer. Electrophoresis was perfomed by the method of LAEMMLI ${ }^{7)}$. 
Active substances were isolated from cultured broth of Streptomyces species such as Streptomyces hygroscopicus by extraction with ethyl acetate, column chromatography on silicic acid, preparative TLC and HPLC on YMC-A312 with $40 \%$ methanol. These substances were identified as acetoxycycloheximide (I) and cycloheximide (II) by high resolution (HR)-MS, IR spectrometry and ${ }^{1} \mathrm{H}$ and ${ }^{13} \mathrm{C}$ NMR spectrometry (Fig. 1).

The morphology of the transformed cells (Hav-NRK cells) characterized by small-sized,

Fig. 1. Chemical structures of acetoxycycloheximide (I) and cycloheximide (II).

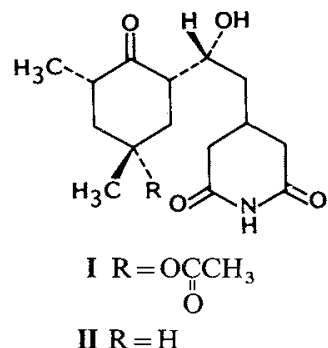

densely stuffed and spindle-shaped cells is shown in Fig. 2A. These cells can reach high cell densities, while the normal cells are flattened out and sensitive to contact inhibition (Fig. 2B). When a fermentation product from Streptomyces species was added to a Hav-NRK cell culture, the cells changed their morphology from the transformed shape to the normal one. With pure acetoxycycloheximide the morphological changes were observed at a concentration of $24.5 \mathrm{ng} / \mathrm{ml}$ ( $72 \mathrm{nM}$, Fig. $2 \mathrm{C}$ ) or more, while with cycloheximide the morphology reverted to normal at a concentration of $390 \mathrm{ng} / \mathrm{ml}(1.4 \mu \mathrm{M}$, Fig. 2D) or more. When the cells were washed free of these agents and allowed to grow in the fresh medium, the normal morphology gradually changed back to the transformed one.

On the other hand, when acetoxycycloheximide or cycloheximide was added at $20 \mu \mathrm{g} / \mathrm{ml}$ to the cultures of Rous sarcoma virus-transformed $3 \mathrm{Y} 1$ cells, Ki-ras transformed NIH3T3 cells, adenovirustransformed 3Y1 cells or Swiss3T3 cells transformed with $a b l$ gene, no morphological change was observed. Thus, it is suggested that acetoxycyclohex-

Fig. 2. Microscopic pictures of Hav-NRK cells (A), NRK cells (B), Hav-NRK cells treated with $24.5 \mathrm{ng} / \mathrm{ml}$ of acetoxycycloheximide (C) and Hav-NRK cells treated with $390 \mathrm{ng} / \mathrm{ml}$ of cycloheximide (D).

(A)

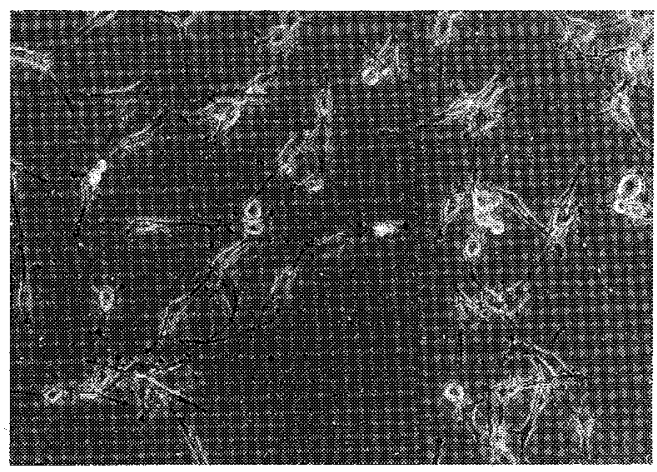

(c)

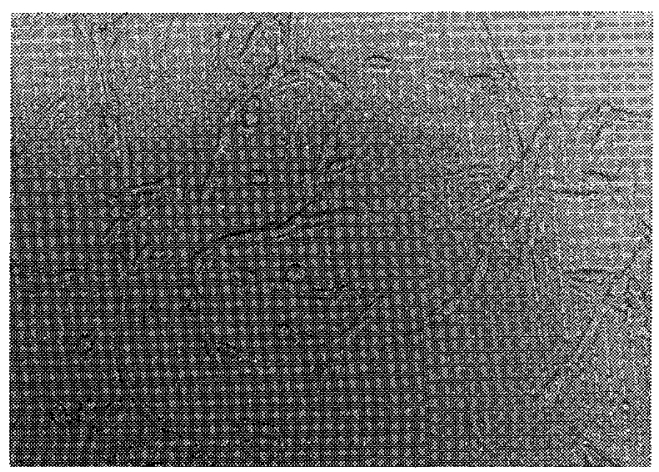

(B)

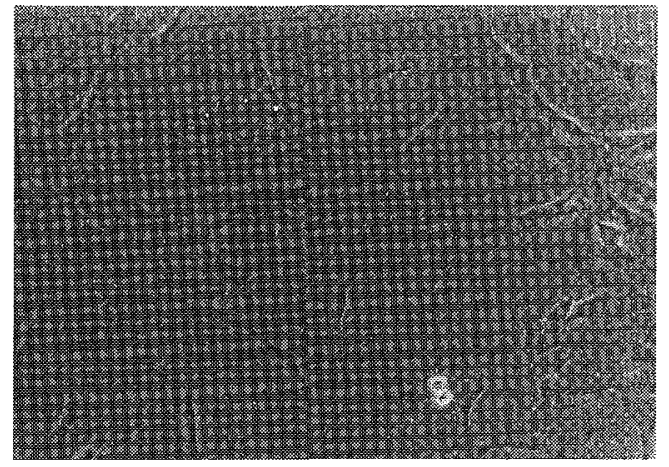

(D)

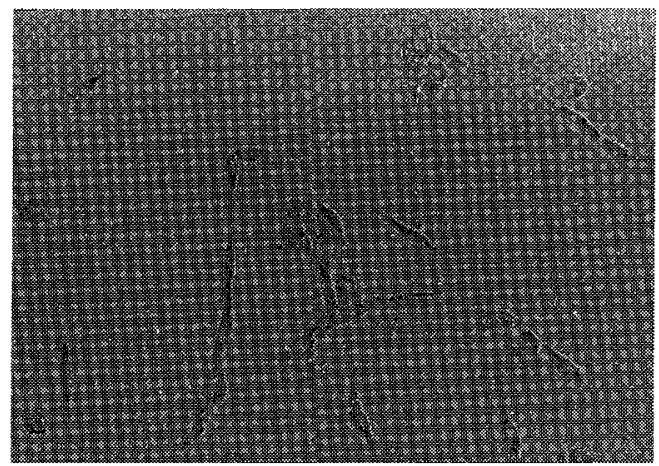


Fig. 3. Analysis of the proteins precipitated with anti-RAS monoclonal antibody by SDS-polyacrylamide gel electrophoresis and autoradiography.

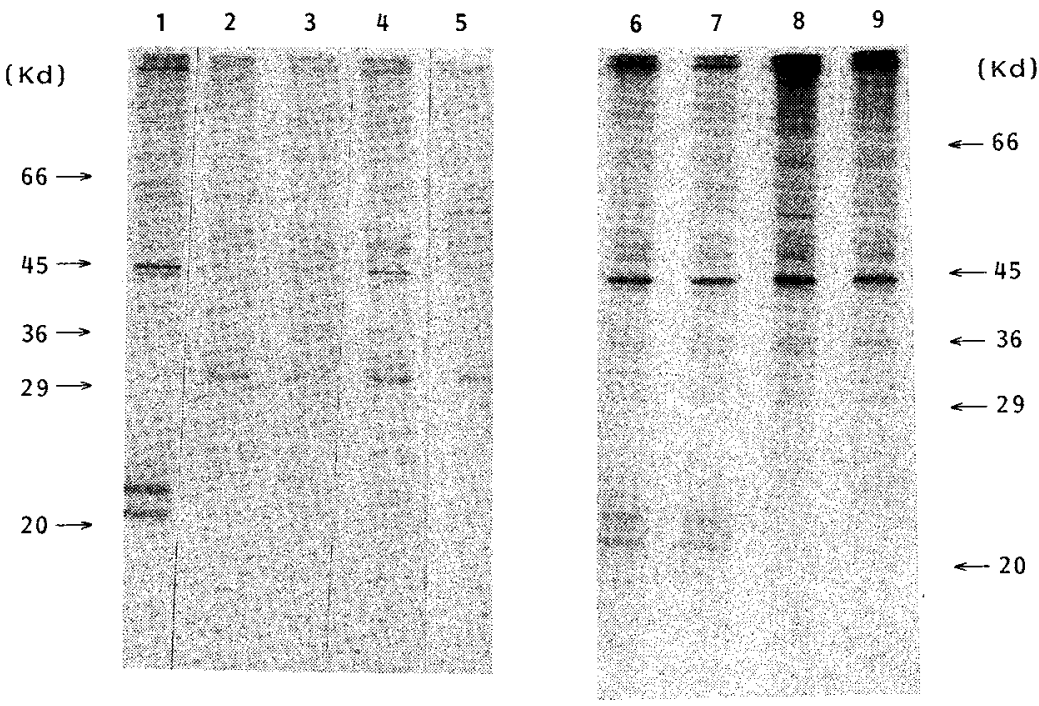

Lane 1: No inhibitor; lane 2: the precipitate with protein A-rat IgG (non-specific precipitation); lane 3: cycloheximide, $390 \mathrm{ng} / \mathrm{ml}$; lane 4: acetoxycycloheximide, $48.9 \mathrm{ng} / \mathrm{ml}$; lane 5: the same as lane 2 but containing acetoxycycloheximide, $48.9 \mathrm{ng} / \mathrm{ml}$; lanes $6 \sim 9$ : competition experiments, concentrations of rat p21 protein were I ng, $10 \mathrm{ng}, 100 \mathrm{ng}$ and $1 \mu \mathrm{g}$ for lanes $6,7,8$ and 9 , respectively. Kd: Kilodalton.

imide and cycloheximide inhibited specifically the process of transformation of the cells by Harveytype ras-oncogene.

Cycloheximide is known to be a specific inhibitor of protein synthesis of eukaryotic cells ${ }^{8)}$ and is used widely as such. The inhibition of protein synthesis was therefore determined in Hav-NRK cells. Acetoxycycloheximide and cycloheximide inhibited the protein synthesis by $50 \%$ at concentrations of 9.8 and $160 \mathrm{ng} / \mathrm{ml}$, respectively. These results suggested that inhibition of protein synthesis might be involved in the recovery of normal morphology of Hav-NRK cells, because both agents caused such morphological changes at concentrations about 2.5 times those required for inhibition of protein synthesis. However, antibiotics known to inhibit protein synthesis of eukaryotic organisms such as puromycin and blasticidin S did not change the morphology of Hav-NRK cells at or less than $50 \mu \mathrm{g} / \mathrm{ml}$, although puromycin at $50 \mu \mathrm{g} / \mathrm{ml}$ and blasticidin $\mathrm{S}$ at $200 \mu \mathrm{g} / \mathrm{ml}$ almost killed the cells. Inhibitors of prokaryotic protein synthesis such as chloramphenicol, josamycin (a macrolide antibiotic), tetracycline, thiostrepton, streptomycin, virginiamycin, capreomycin, lincomycin, fusidic acid and mitomycin did not also cause the morphological recovery at $50 \mu \mathrm{g} / \mathrm{ml}$. It is suggested therefore that the morphological change of the ras-transformed Hav-NRK cells is specifically caused by acetoxycycloheximide and cycloheximide. Analysis of the proteins precipitated by anti-RAS monoclonal antibody revealed that the synthesis of $\mathrm{p} 21$ proteins was preferentially inhibited by cycloheximide or acetoxycycloheximide, compared to other proteins (Fig. 3, lanes 3 and 4). In these experiments, the biosynthesis of total protein was inhibited by 73.3 and $59.9 \%$ by cycloheximide and acetoxycycloheximide, respectively, while that of $\mathrm{p} 21$ protein was decreased to almost zero and $7.9 \%$, respectively. On the other hand, puromycin at $30 \mu \mathrm{g} / \mathrm{ml}$ and blasticidin $\mathrm{S}$ at $10 \mu \mathrm{g} / \mathrm{ml}$ inhibited the biosynthesis of total protein by 61 and $61 \%$ respectively, while that of p 21 was decreased to 64 and $69 \%$, respectively. Thus, these results indicate that acetoxycycloheximide and cycloheximide change the morphology of the transformed cells by inhibiting the biosynthesis of $\mathrm{p} 21$ protein preferentially. Although two bands were detectable near 21,000 daltons in the autoradiogram, competition experiment clearly showed that they were derived from $\mathrm{p} 21$ protein (Fig. 3 , lanes $6,7,8$ and 9). One may be a degradation product. 


\section{Acknowledgment}

We thank S. J. Lucania, H. Yoshikura, S. Kawai, N. TsUCHIDA and K. SHIROKI for generous gifts of thiostrepton and various cell lines, Hideo SUZUKI of the University of Tokyo for his helpful suggestion and I. SuzUKI and M. TOKI for their technical assistance. This work was supported in part by the Grants-in-Aid for Cancer Research from the Ministry of Education, Science and Culture of Japan and from the Suzuken Foundation.

\section{Hiroshi Ogawara YAYOI HASUMI KYOICHIRO HIGASHI YOSHIAKI ISHII}

Department of Biochemistry, Meiji College of Pharmacy, 1-35-23 Nozawa, Setagaya-ku, Tokyo 154, Japan

\section{TAKESHI SAITO SHUN-ICHI WaTANABE KEN-ICHI SUZUKI MASATO KOBORI KO-ICHI TANAKA}

Central Research Institute, Yamanouchi Pharmaceutical Co., Ltd., 1-1-8 Azusawa, Itabashi-ku, Tokyo 174, Japan

\section{Tetsu Akiyama}

Department of Pathology,
Institute of Virus Research, Kyoto University, Kawahara-machi, Shogo-in, Sakyo-ku, Kyoto 602, Japan

(Received February 20, 1989)

\section{References}

1) Bishop, J. M.: Cellular oncogenes and retroviruses. Annu. Rev. Biochem. 52: $301 \sim 354,1983$

2) Ogawara, H.; T. Akiyama, J. Ishida, S. Watanabe $\&$ K. SuzuKI: A specific inhibitor for tyrosine protein kinase from Pseudomonas. J. Antibiotics 39: 606 608,1986

3) AkiYama, T.; J. Ishida, S. NaKagawa, H. OgaWara, S. Watanabe, N. Itoh, M. Shibuya \& Y. FuKam: Genistein, a specific inhibitor of tyrosine-specific protein kinases. J. Biol. Chem. 262: 5592 5595, 1987

4) Barbacid, M.: ras genes. Annu. Rev. Biochem. 56: $779 \sim 827,1987$

5) Nishimura, S. \& T. Sekiya: Human cancer and cellular oncogenes. Biochem. J. 243: $313 \sim 327,1987$

6) KERRIDGE, D.: The effect of actidione and other antifungal agents on nucleic acid and protein synthesis in Saccharomyces carlsbergensis. J. Gen. Microbiol. 19: 497 506, 1958

7) LAEMMLI, U. K.: Cleavage of structural proteins during the assembly of the head of the bacteriophage T4. Nature 227: $680 \sim 685,1970$

8) Colombo, B.; L. Felicetti \& C. Baglion: Identification of protein synthesis in retinculocytes by antibiotics. I. Effects on polysomes. Biochim. Biophys. Acta 119: 109 119, 1966 